EREM 74/4

Journal of Environmental Research, Engineering and Management Vol. 74 / No. 4 / 2018

pp. 7-18

DOI 10.5755/j01.erem.74.4.22119

(C) Kaunas University of Technology

\section{Continuous Improvement of Employee Engagement: Impact on Quality Management System}

Received 2018/11

Accepted after revision 2018/11

\title{
Continuous Improvement
} of Employee Engagement: Impact on Quality Management System

\author{
Eglè Staniškienè, Asta Daunorienè, Živilè Stankevičiūtè
}

Kaunas University of Technology, School of Business and Economics, Gedimino str. 50, Kaunas, Lithuania

Corresponding author: egle.staniskiene@ktu.lt

E. Staniškienè, Kaunas University of Technology, School of Business and Economics, Gedimino str. 50, Kaunas, Lithuania

During the last years, quality management system has been implemented to foster organizational, cultural and management changes. Moreover, based on the employee engagement processes and the results, an idea was developed to promote and encourage employees for proactive quality improvement decisions. However, the complicated nature of quality management system did not support expected results. Firstly, the employees do not relate their quality activities as a possibility to increase effectiveness of entire organization. Secondly, the introduction of quality management system for employees is associated with appearance of complementary control actions (Mickaitis et al., 2009). This paper aims at focusing on the employee engagement and its impact on the quality management system. The goal of the research is to create an employee engagement into quality management system model in order to determine the relationship between the employee behavior and employee engagement in the quality management system, as well as to evaluate its applicability in the case of local government institutions. In order to test empirically constructed model a survey was conducted on a sample of 336 employees of a local government institution. The result of the study is an employee engagement into quality management system model for the measurement an organization employee engagement impact on quality management system.

Keywords: Employee engagement, quality management system, planned behavior theory. 


\section{Introduction}

For many years scientists acknowledge that the employee engagement is crucial for the organization performance management (Gruman \& Saks, 2011). Robinson et al. (2004:1) define employee engagement as " $<\ldots$.. a positive attitude held by the employee towards the organization and its value. An engaged employee is aware of business context, and works with colleagues to improve performance within the job for the benefit of the organization. Kompaso and Sridevi (2010) state that ,engaged employees are emotionally attached to their organization and highly engaged in their job with a great enthusiasm for the success of their employer <...> (Kompaso and Sridevi, 2010:89). Mohsan et al. (2011) maintain that today's organizations are aware of each employee's engagement to the organization's goals and tasks achievement, and it is very important that the results of the work are recognized (Mohsan et al., 2011).

Research results conducted by Sadikoglu and Zehir (2010) show indirect impact of employee engagement in organization performance through innovation performance. The quality management standards highlight the importance of employees' engagement. The rationale for this principle is that the engagement of employees in achieving the goals of an organization contributes to the implementation of the organization's strategy, policies and processes.

Hanaysha (2016) states that employee engagement depends on employee satisfaction and motivation. While, the other scientists focus on the on individual factors (e.g. age, gender, education, etc.) and situational factors (e.g. the nature of work, the environment, working conditions, etc.). Anitha's (2014) study addressed the factors that determine employee engagement: leadership, environment, strategy, wellbeing, politics, etc. Anitha (2014) argues that reward motivates employee to achieve more by focusing not only on the job itself, but also on personal development. Rabindarang et al. (2014) state that socio-demographic factors: age, gender, work experience can influence employee engagement as well.

Engagement of employees could also be described as a particular behaviour with additional roles. According to Baumruk (2006), a behaviour of the engaged employee striving to increase organization's efficiency is characterized by a positive response about his organization, a desire to be its member and major efforts undertaken. In order to determine the behaviour of an employee in regard to a particular target, the theory of planned behaviour could be used. Jacobs (2016) state that the application of this theory is successful in predicting different behaviours. Predictive behaviour is useful, since an attitude based on perception encourages employee behaviour that influences the attainment of goals by certain subjective norms.

The theory of planned behaviour and different employee engagement determinants reflect on the cognitive psychology intentions such as subjective norm, attitude towards behaviour, etc. Application of a planned behaviour theory in the research of engagement of employees into the quality management system is promising, because in such a way, employee's perception and intention to behave according to the requirements of the quality management system can be assessed. This theory, according to Ajzen (1991), foresees and explains individual's behaviour in specific contexts, and based on it, the analysis of connections of intention and real behaviour is available.

There are numerous models to measure employee engagement. Energy and dedication to work may be considered as cornerstones by many scholars to help assess employees' engagement in the work. Schaufeli and Bakker (2010) developed the Utrecht scale, which is based on 17 employee engagement statements. Kahn (1990), May et all (2004), Shuck et al., (2011) analyzed the determinants of employee engagement through a psychological condition. A person who has a meaningful job, psychological safety and availability is considered to be engaged in work. The other model of engagement emphasizes three psychological characteristics that reflect on the employee engagement:

meaningfulness is feedback, a perception that work is meaningful and important. Subsequent theoretical and empirical studies expanded this phenomenon, and meaningfulness was reported as work match or improvement.

security is the ability to work without worrying about the negative impact of the employee image, status, or career (Kahn, 1990). 
eligibility is the employee conviction that he has physical, emotional and cognitive abilities to be engagement.

The practitioners present effectiveness of organization performance within quality management system and engagement of employees at all levels of quality management system. However, the impact of employee engagement on quality management is poorly analysed. This paper aims to analyse the employee engagement more in depth focussing on the impact on the quality management system.

\section{Methods}

Scientific literature analysis indicates that engagement of employees is one of the principles of the quality management system. Jacobs (2016) highlights that the organizations which have a standardized quality management system should make efforts to engaged employees into this system in accordance to its requirements, i.e. would behave as it is expected by implementing requirements of the quality management system. The scientist states that successful implementation of the quality management system depends on behaviour of employees. However, human behaviour depends on a situation and subjective norms; therefore, a behaviour is a hardly predictable issue. With a reference to the planned behaviour theory, it is possible to forecast behaviour of employees in regard to the quality management system, because the stronger intentions of employees to follow properly the requirements of the quality management system, the easier they engage into the system. But, first, it is necessary to find out employees' attitude towards efficiency of the quality management system and subjective norms as well as of a perceived behaviour control that also directly affect behaviour of employees in regard to the quality management system. This information can be very useful in striving for a favourable behaviour of employees at work, helping to implement the requirements of the quality management system and engaging employees into the system. Jacobs (2016) stated that application of this theory is successful in forecasting different forms of the behaviour. The author states that, forecasting of behaviour is useful, because the attitude is based on the perception; particular subjective norms stimulate a behaviour that has influence reaching the goals.

Scientific literature review helped to determine different factors engaging employees into the quality management system and criteria that helps to measure engagement of employees. In the employee engagement research, a most variety of research methods that help to assess the impact of these factors on the employee engagement and the significance of criteria could be used.

Literature analysis reveals that engagement of employees is related to subjective well-being. Matthews et all (2014) determines that engagement of employees is positively related to subjective well-being. The authors' states that the employees satisfied in their life are mostly characterized by positive emotions, more efficient work results; therefore, their engagement into the organization's activity is simpler. These employees by their behaviour stimulate other employees to be engaged. Due to these reasons, during the research, it was decided to examine subjective well-being of employees as one of the factors determining engagement of employees. According to the statement of Mohapatra and Sharma (2010), Rabindarang et al. (2014), Gaurylienè and Korsakienè (2017), in order to assess engagement of employees, it is necessary to consider employees' socio-demographic factors, such as gender, age, work experience. Pitt-Catsouphes and Matz-Costa (2009), Rabindarang et all (2014) emphasize that age is related to engagement. The authors states that older employees are more engaged than younger employees. Reissová et all (2017) by the examining employee engagement with atmosphere in the workplace, satisfaction with management and potential staff turnover, found out that women are more engaged than men. Attridge (2009) states that more experienced employees are more engaged in their work they are.

Based on the analysis of scientific literature, the theoretical model of employee engagement in the quality management system was developed (see fig 1).

As such, this paper proposed that employee engagement in work and employee behaviour on the quality 
Fig. 1

Conceptual model for estimation results

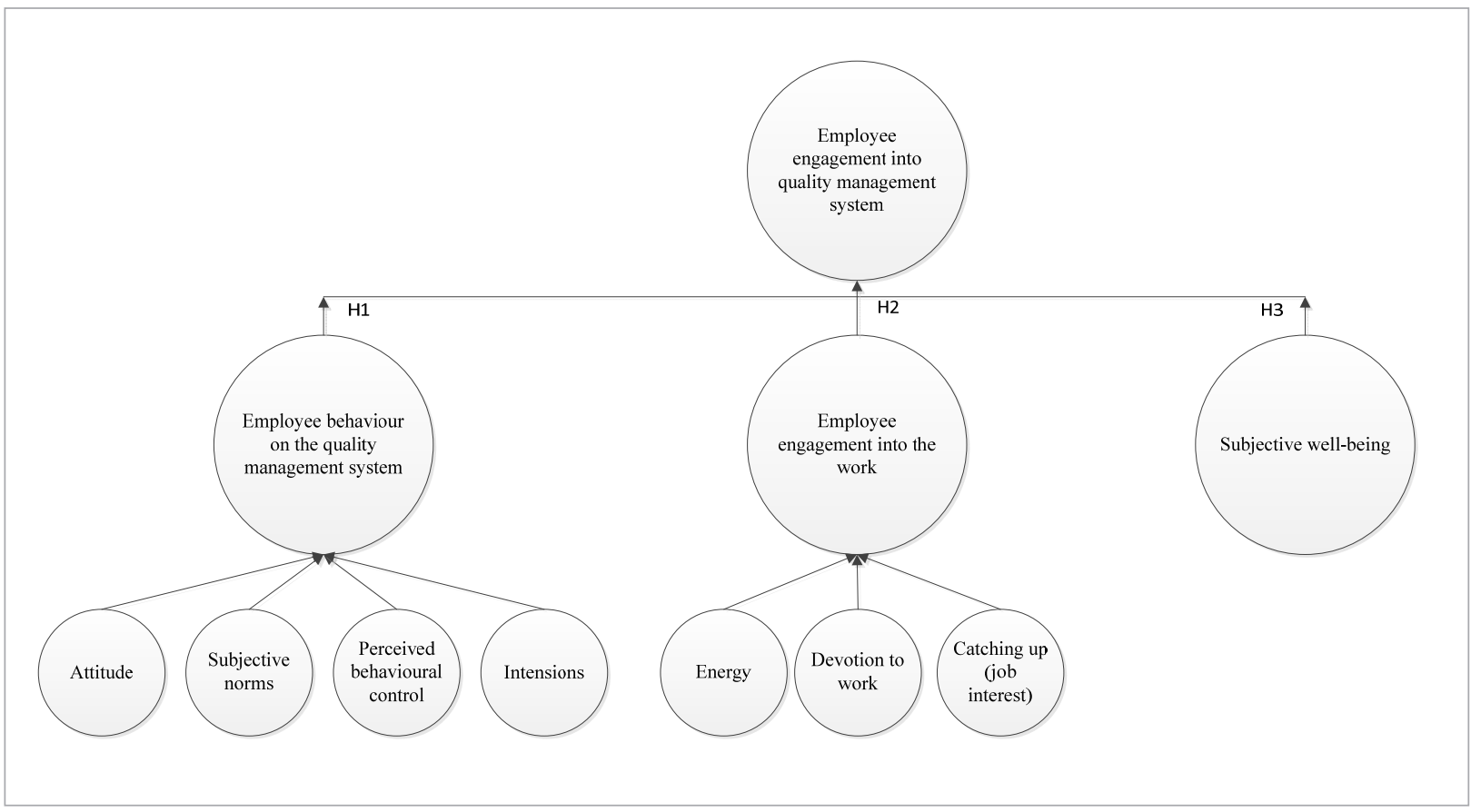

management system as well as subjective wellbeing will have a positive influence on employee engagement into quality management system. The statement was divided into a sequence of hypothesis.

H1 Employee behaviour on the quality management system will have a positive influence on employee engagement in quality management system.

H2. Employee engagement into the work will have a positive influence on employee engagement in quality management system.

H3. Subjective well-being will have a positive influence on employee engagement into quality management system.

Since the aim of the research was to test employee engagement impact on quality management system the instrument used to test the constructed model was an electronic survey. All survey statements were based on the different model constructs which were fulfilled with validated research questionnaires variables. The survey questions were divided into three groups of statements (see Table 1). The first group covered 35 statements that helped to indicate employees' behaviour on the quality management system (Jakobs, 2016). All statements were measured with a seven-time Likert scale (1 = "highly unlikely"; $<\ldots>$ and 7 = "highly likely"). The second group of questions helped to determine the employee engagement in work. This group of questions was based on the Schaufeli and Bakker (2010:714) 17 statements which were measured six-time Likert scale (1= "highly unlikely", <...> and $6=$ "highly likely", the third group of questions by Diener et al. (1985) indicated the subjective well-being aspects and, were based on a seventime Likert scale. The last part of the questionnaire was devoted to the socio-demographic details. The research was based on quantitative research basis.

To examine employee engagement into quality management system, the research data was collected through national government institutions located in Lithuania. National government institutions which are accountable to the government where chosen within dedication of the implementation of quality management system. A 350 research simple with a 5\% error 


\section{Table 1}

Questionnaire constructs

\begin{tabular}{|c|c|c|c|}
\hline $\begin{array}{l}\text { Theoretical } \\
\text { model construct }\end{array}$ & Latent/measurable statements & $\begin{array}{l}\text { Number of } \\
\text { statements }\end{array}$ & Source \\
\hline 1 & 2 & 3 & 4 \\
\hline $\begin{array}{l}\text { The attitude } \\
\text { to the quality } \\
\text { management } \\
\text { system and its } \\
\text { efficiency }\end{array}$ & $\begin{array}{l}\text { Having a quality management system is beneficial to me and organization. } \\
\text { Having a quality management system increases the efficiency and profitability of the } \\
\text { company } \\
\text { Quality management system trainings help me to learn why I need to implement the } \\
\text { system and what I have to do } \\
\text { Quality management standart is a useful standard and the requirements are reasonable }\end{array}$ & $\begin{array}{l}5 \\
3 \\
3 \\
3\end{array}$ & $\begin{array}{c}\text { (Jakobs, } \\
2016 \text { ) }\end{array}$ \\
\hline $\begin{array}{l}\text { Subjective } \\
\text { norms }\end{array}$ & $\begin{array}{l}\text { It is expected that I comply with quality management system requirements } \\
\text { My family and friends expect me to follow rules and requirements of work } \\
\text { I am influenced by what I see others do }\end{array}$ & $\begin{array}{l}3 \\
2 \\
2\end{array}$ & $\begin{array}{c}\text { (Jakobs, } \\
\text { 2016) }\end{array}$ \\
\hline $\begin{array}{l}\text { Perceived } \\
\text { behavioural } \\
\text { control }\end{array}$ & $\begin{array}{l}\text { I have impact to quality management system requirements affecting me } \\
\text { I have authority to complete tasks assigned to me } \\
\text { My opinion is valued }\end{array}$ & $\begin{array}{l}2 \\
2 \\
3\end{array}$ & $\begin{array}{c}\text { (Jakobs, } \\
\text { 2016) }\end{array}$ \\
\hline Intentions & $\begin{array}{l}\text { I want to comply with quality management system requirements } \\
\text { I intend to contribute to the success of organization } \\
\text { My intention to be compliant at work }\end{array}$ & $\begin{array}{l}3 \\
2 \\
2\end{array}$ & $\begin{array}{l}\text { Jakobs, } \\
(2016)\end{array}$ \\
\hline Energy & $\begin{array}{l}\text { At my work, I feel bursting with energy } \\
\text { At my work, I feel strong and vigorous } \\
\text { When I get up in the morning, I feel like going to work } \\
\text { I can continue working for very long periods at a time } \\
\text { At my work I am very resilient, mentally } \\
\text { At my work, I always persevere, even when things do not go well }\end{array}$ & & $\begin{array}{l}\text { Schaufeli } \\
\text { and } \\
\text { Bakker } \\
(2010)\end{array}$ \\
\hline $\begin{array}{l}\text { Devotion to } \\
\text { work }\end{array}$ & $\begin{array}{l}\text { I find the work that I do full of meaning and purpose } \\
\text { I am enthusiastic about my work } \\
\text { My work inspires me } \\
\text { I am proud of the work that I do } \\
\text { To me, my work is challenging }\end{array}$ & & $\begin{array}{l}\text { Schaufeli } \\
\text { and } \\
\text { Bakker } \\
(2010)\end{array}$ \\
\hline $\begin{array}{l}\text { Catching up } \\
\text { (job interest) }\end{array}$ & $\begin{array}{l}\text { Time flies when I am working } \\
\text { When I am working, I forget everything else around me } \\
\text { I feel happy when I am working intensely } \\
\text { I am immersed in my work } \\
\text { I get carried away when I am working } \\
\text { It is difficult to detach myself from my work }\end{array}$ & & $\begin{array}{l}\text { Schaufeli } \\
\text { and } \\
\text { Bakker } \\
(2010)\end{array}$ \\
\hline $\begin{array}{l}\text { Subjective well } \\
\text { being }\end{array}$ & $\begin{array}{l}\text { In many ways, my life is almost perfect } \\
\text { My living conditions are great } \\
\text { I'm pleased with my life } \\
\text { So far, in my life, I have received important things which I wanted } \\
\text { If I could live my life again, I would not change almost anything }\end{array}$ & & $\begin{array}{l}\text { Diener et } \\
\text { al. (1985) }\end{array}$ \\
\hline
\end{tabular}

(Kaynak, 2003), which indicates the reliability of the data was calculated on the employees employed by national government institutions basis. An electronic survey was sent via email. From initial frame of 350 institutions employees' surveys, 14 error surveys were removed from the data sample. Data collection took over 10 months. The survey was stopped when the required amount of full questionnaires was collected. Table 2 provides respondents socio-demographic profile. 


\section{Table 2}

Respondents socio-demographic profile

\begin{tabular}{l|c|c}
\hline \multicolumn{1}{|c|}{ Characteristics } & Frequency $(\mathrm{n})$ & Percentage (\%) \\
\hline \multicolumn{1}{|c|}{ Gender } & 2 & 3 \\
$\begin{array}{l}\text { Female } \\
\text { Male }\end{array}$ & 223 & 61 \\
\hline Age & 113 & 39 \\
$26-35$ & & \\
$36-45$ & 66 & 18 \\
$46-55$ & 213 & 59 \\
56 and up & 72 & 20 \\
\hline Work experience in the & 12 & 3 \\
organization & 272 & 75 \\
Up to 5 & 76 & 21 \\
From 6 to 9 & 15 & 4 \\
More than 10 & & \\
\hline
\end{tabular}

In the groups of respondents there were more females than males. 59\% employees were at the age between 36 and 44 ; the other $20 \%$ of employees were at the age group from 46 to 55 , and $18 \%$ of employees were at the age from 26 and $35.75 \%$ of respondents had up to 5 year of work experience, $21 \%$ - from 6 to $9,4 \%$ - more than 10 years. The socio-demographic profile of respondents let us to make an assumption that employees are loyal to analysed local government institutions with several years of experience. Evaluation of the engagement of these employees in the quality management system were important as they were well acquainted with the system and can recall its advantages and disadvantages.

The analytics procedure of this study included descriptive statistics, reliability and correlation analysis. Reliability analysis was conducted in terms of consistency. Cronbach's a (see 3 and 4 tables) was calculated for each scale. For this research scale of Cronbach's a scale was respectable if Cronbach's a value varies from 0.7 (DeVellis, 2016). Thus, it means that employee engagement in work, subjective well-being, Employee behaviour on the quality management system were higher than 0.7 value.

Hypothesis testing was accomplished using Pearson correlation coefficient, the same coefficient was calculated to test correlations between constructs and socio-demographic variables. This connection was

\section{Table 3}

Construct scale (measured by seven-time Likert scale) items reliability analysis

\begin{tabular}{l|c}
\hline \multicolumn{1}{|c|}{ Theoretical model construct items } & Cronbach alpha \\
\hline \multicolumn{1}{|c|}{1} & 2 \\
\hline Employee engagement in work & .870 \\
\hline The attitude to the quality management & .876 \\
system and its efficiency & .874 \\
\hline Subjective norms & .881 \\
\hline Perceived behavioural control & .886 \\
\hline Intentions & .874 \\
\hline Subjective well being
\end{tabular}

\section{Table 4}

Construct scale (measured by six-time Likert scale) items reliability analysis

\begin{tabular}{l|c}
\hline \multicolumn{1}{|c|}{ Theoretical model construct items } & Cronbach alpha \\
\hline \multicolumn{1}{c|}{1} & 2 \\
\hline $\begin{array}{l}\text { Employee behaviour on the quality } \\
\text { management system }\end{array}$ & .868 \\
\hline Energy & .870 \\
\hline Devotion to work & .867 \\
\hline Catching up (job interest) & .869 \\
\hline
\end{tabular}

expressed in ranks from 0 (no correlation) to \pm 1 (excellent correlation). Negative correlation showed negative impact on the theoretical model construct items, therefore -1 showed very strong inverse correlation (Noru, 2012). Moreover, to test hypothesis of the conceptual model and to perform correlation between constructs all the scores of each sub-scale were computed.

\section{Results and Discussion}

The study aimed to determine what influence the behaviour of employees in relation to the quality management system: the attitude to the quality management system and its efficiency, subjective norms, perceived behavioural control, intentions (see Table 5).

The results of the research showed that a very strong correlation was found between the attitude to the 
quality management system and its efficiency and the employee engagement into the work $(r=0.933$, $p<0.01$ ). It can be argued that strengthening employees' attitudes will increase the behaviour of employees in relation to the quality management system. It was found that the behaviour of employees with subjective norms and its efficiency and the employee engagement in work was related to strong relationships significant in statistics $(r=0.849, p<0.01)$. The same strong and positive correlation was identified with perceived behavioural control and intentions variables and employee engagement in work.

\section{Table 5}

Conceptual model: Employee engagement in work correlation matrix

\begin{tabular}{|c|c|c|c|c|c|}
\hline & & $\begin{array}{l}\text { The attitude to the } \\
\text { quality management } \\
\text { system and its } \\
\text { efficiency }\end{array}$ & $\begin{array}{c}\text { Subjective } \\
\text { norms }\end{array}$ & $\begin{array}{l}\text { Perceived } \\
\text { behavioural } \\
\text { control }\end{array}$ & Intentions \\
\hline \multirow{2}{*}{ Employee engagement in work } & $\begin{array}{l}\text { Pearson } \\
\text { correlation }\end{array}$ & $.933^{* *}$ & $.849^{* *}$ & $.802^{\star *}$ & $.759^{\star \star}$ \\
\hline & Sig. (2-tailed) & .000 & .000 & .000 & .000 \\
\hline
\end{tabular}

** Correlation is significant at the 0.01 level (2-tailed)

\section{Table 6}

Correlation between the employee engagement in work constructs items and socio-demographic profile

\begin{tabular}{|c|c|c|c|c|}
\hline & \multirow{3}{*}{$\begin{array}{c}\text { Gender } \\
.032\end{array}$} & \multirow{3}{*}{$\begin{array}{l}\text { Age } \\
.546^{* *}\end{array}$} & \multirow{3}{*}{$\begin{array}{c}\text { Work experience in the } \\
\text { organization } \\
.431^{\star *}\end{array}$} \\
\hline & & & & \\
\hline Emplovee enqaaement in work & $\begin{array}{l}\text { Pearson } \\
\text { correlation }\end{array}$ & & & \\
\hline & Sig. (2-tailed) & .650 & .000 & .000 \\
\hline \multirow{2}{*}{$\begin{array}{l}\text { The attitude to the quality management system and } \\
\text { its efficiency }\end{array}$} & $\begin{array}{l}\text { Pearson } \\
\text { correlation }\end{array}$ & .049 & .204 & $.330^{* *}$ \\
\hline & Sig. (2-tailed) & .639 & .052 & .001 \\
\hline \multirow{2}{*}{ Subjective norms } & $\begin{array}{l}\text { Pearson } \\
\text { correlation }\end{array}$ & $-.405^{\star *}$ & $.263^{*}$ & .119 \\
\hline & Sig. (2-tailed) & .002 & ,012 & .260 \\
\hline \multirow[t]{2}{*}{ Perceived behavioural control } & $\begin{array}{l}\text { Pearson } \\
\text { correlation }\end{array}$ & .016 & $.458^{* *}$ & $.215^{*}$ \\
\hline & Sig. (2-tailed) & .915 & .000 & .047 \\
\hline \multirow[t]{2}{*}{ Intentions } & $\begin{array}{l}\text { Pearson } \\
\text { correlation }\end{array}$ & .025 & $.457^{* *}$ & $.365^{*}$ \\
\hline & Sig. (2-tailed) & 0.852 & .001 & .050 \\
\hline
\end{tabular}

** Correlation is significant at the 0.05 level (2-tailed)

${ }^{* *}$ Correlation is significant at the 0.01 level (2-tailed) 
The study revealed that the average correlation is among employee engagement in work and the age of employees, and work experience in the organization. It is likely that the benefits of the quality management system and the validity of its requirements are differently assessed by respondents of different age groups and different work experience in the organization.

The average positive correlation was found between the employees' attitudes to the quality management system and its efficiency. It can be assumed that when employee works in the organization for a long time, his (her) approach to the positive benefits to the attitude to the quality management system and its efficiency is changing.
The average negative correlation was found between subjective norms and gender and the positive correlation between ages. It can be assumed that the subjective norms can be negatively interpreted by gender. Moreover, the results revealed that the subjective norms can be negatively interpreted by the females.

The research revealed that employee behaviour in the quality management system, energy, devotion to work, catching up (job interest) were linked together with statistically significant positive correlation relations. Increasing energy, devotion to work, catching up (job interest) will help employees to become more interested in their work and quality management system. A statistically significant correlation between

\section{Table 7}

Conceptual model: Employee behaviour on the quality management system correlation matrix

\begin{tabular}{l|c|c|c|c}
\hline \multicolumn{2}{|c|}{} & Energy & Devotion to work & Catching up (job interest) \\
\hline $\begin{array}{l}\text { Employee behaviour on the quality } \\
\text { management system }\end{array}$ & Pearson correlation &, $404^{* *}$ &, $467^{\star *}$ &, $293^{\star *}$ \\
\cline { 2 - 5 } & Sig. (2-tailed) & .003 & .005 & .002 \\
\hline
\end{tabular}

** Correlation is significant at the 0.01 level (2-tailed).

\section{Table 8}

Correlation between the employee behaviour in the quality management system constructs items and socio-demographic profile

\begin{tabular}{|c|c|c|c|c|}
\hline & & Gender & Age & $\begin{array}{l}\text { Work experience } \\
\text { in the organization }\end{array}$ \\
\hline \multirow{2}{*}{$\begin{array}{l}\text { Employee behaviour in the quality } \\
\text { management system }\end{array}$} & Pearson correlation & $.251^{*}$ & $0.528^{*}$ & 0.85 \\
\hline & Sig. (2-tailed) & .002 & .087 & .032 \\
\hline \multirow{2}{*}{ Energy } & Pearson correlation & .076 & .189 & .013 \\
\hline & Sig. (2-tailed) & .477 & .073 & .902 \\
\hline \multirow{2}{*}{ Devotion to work } & Pearson correlation & $.221^{*}$ & $.275^{* *}$ & .115 \\
\hline & Sig. (2-tailed) & .035 & .008 & .278 \\
\hline \multirow{2}{*}{ Catching up (job interest) } & Pearson correlation & $.414^{* *}$ & $.229^{*}$ & .187 \\
\hline & Sig. (2-tailed) & .002 & .036 & .058 \\
\hline
\end{tabular}

\footnotetext{
${ }^{*}$ Correlation is significant at the 0.05 level (2-tailed) $<0.05$
}

** Correlation is significant at the 0.01 level $(2$-tailed $)<0.01$ 


\section{Table 9}

Correlation between the subjective wellbeing and socio-demographic profile

\begin{tabular}{l|c|c|c|c}
\hline \multicolumn{2}{c|}{} & Gender & Age & $\begin{array}{c}\text { Work experience } \\
\text { in the organization }\end{array}$ \\
\hline \multirow{2}{*}{ Subjective well-being } & Pearson correlation &, 004 &,$- 306^{* *}$ &,$- 226^{*}$ \\
\cline { 2 - 5 } & Sig. (2-tailed) &, 970 &, 003 &, 001 \\
\hline
\end{tabular}

${ }^{* *}$ Correlation is significant at the 0.01 level (2-tailed) $<0.01$

Table 10

Conceptual model: Employee engagement in quality management system construct correlation

\begin{tabular}{l|c|c|c|c}
\hline \multicolumn{2}{c|}{} & $\begin{array}{c}\text { Employee } \\
\text { engagement in } \\
\text { work }\end{array}$ & $\begin{array}{c}\text { Employee be- } \\
\text { haviour on the } \\
\text { quality manage- } \\
\text { ment system }\end{array}$ & $\begin{array}{c}\text { Subjective well } \\
\text { being }\end{array}$ \\
\hline $\begin{array}{l}\text { Employee engagement in quality } \\
\text { management system }\end{array}$ & Pearson correlation &, $735^{* *}$ &, $374^{* *}$ &, $583^{* *}$ \\
\cline { 2 - 5 } & Sig. (2-tailed) & .000 & .008 & .000 \\
\hline
\end{tabular}

${ }^{* *}$ Correlation is significant at the 0.01 level (2-tailed)

these variables shows that by strengthening certain components of the behaviour, it is possible to achieve positive attitude to the quality management system.

The analysis of scientific literature revealed that socio-demographic factors can influence the employee behaviour in the quality management system. The results of the study indicated statistically significant link between employee behaviour in the quality management system and employee gender and age (see table 8). Moreover, the research results that the employee devotion to work (stronger correlation between females than males and more experienced employees (working at the institution from 6 and more years) and catching up (stronger correlation between females than males) can make a positive impact on the behaviour in the quality management system.

The study found that a statistically negative weak correlation between subjective well-being and age as well as work experience in the organization. The correlation did not show any differences between male and female.

Moreover, age (the older employee is), work experience in the organization (the more employee is experienced) are likely to decrease subjective well-being.

The results of the correlation analysis indicated very strong positive linkage between employee engagement in quality management system and employee engagement in work, weak positive correlation between employee behaviour in the quality management system and employee engagement into quality management system, and average positive correlation between subjective wellbeing and employee engagement in quality management system. These findings indicate that conceptual model variables are related and support all hypotheses (see Table 11). Accordingly, the literature review findings and arguments for articulating role of employee engagement to quality management system and operationalizing the model is strongly supported by data.

Summarizing the results of the research, it was found that the employee socio-demographic features affect the empowerment of employees. Moreover, it is a complex attitude that helps to gain deeper understanding of employee empowerment impact to quality management system. 


\section{Table 11}

Summary of hypotheses and findings

\begin{tabular}{l|c|c}
\hline \multicolumn{1}{c|}{ Hypotheses } & Relationships & Findings \\
\hline $\begin{array}{l}\text { H1 Employee behaviour in the quality management system will have a positive influence on } \\
\text { employee engagement in quality management system. }\end{array}$ & Positive & Supported \\
\hline $\begin{array}{l}\text { H2. Employee engagement in work will have a positive influence on employee engagement into } \\
\text { quality management system. }\end{array}$ & Positive & Supported \\
\hline $\begin{array}{l}\text { H3. Subjective well-being will have a positive influence on employee engagement into quality } \\
\text { management system. }\end{array}$ & Positive & Supported \\
\hline
\end{tabular}

\section{Conclusions}

The research was striving to reveal empowerment of employees in a quality management system. It is likely that empowerment of employees in the system depends on empowerment of employees into work in organization and on their behaviour in point of view of the quality management system. Due to these reasons, the empowerment of employees in work was assessed, based on components of energy, devotion and catching up to work. The research was striving to assess behaviour of employees in terms of the quality management system, based on their attitude towards the system, subjective norms, control of a perceived behaviour and intentions to follow the requirements of the quality management system.

Summarizing the research results, it could be assumed that by strengthening employee's attitude towards benefits of the quality management system, their engagement into it will be strengthened. The results indicate that employees favourably assess the quality management system in organization. It is likely that such assessments by employees are affected by trainings on the quality management system performed in the organization, during which the employees are being familiarized with the system, its requirements being explained. The importance of the training was highlighted during a survey. However, employees' attitude towards the quality management system has to be strengthened constantly. Only by perceiving benefits of the system, the employees will tend to be engaged into it. It is advisable to describe the quality management system to employees as a measure that helps to solve their work quality problems, facilitate their work processes rather that aggravate them.

The relationship between employee's willingness to contribute organization's success and engagement into work is also expressed stronger than others. It can be assumed that the employees engaged into the quality management system are guided by a desire to be a part of a successful organization by contributing to implementation of organizational goals, aspiration to give clients as qualitative as possible services that corresponds expectations of the clients. According to Kaziliūnas and Vyšniauskienè (2014), thus, one of quality management principles - engagement of employees is implemented. The management should pay attention to intentions of these employees and stimulate them to be engaged into implementation of the quality management system installed in the organization by listening opinion of employees, going deeper into their expectations. Kaziliunas and Vyšniauskiene (2014) highlight that the employees engaged in the quality management system are more motivated, loyal to organization, responsible for their activity and more willingly contribute to organizational processes.

By using the correlation analysis method, there was analysed a relationship between the constructs under research and the summarized components forming them. The researches indicate that there is a statistically significant average correlation between behaviour of employees in point of view of the quality management system and summarized structural components of employees' engagement. It can be assumed that stimulation of favourable behaviour of an employee with regard 
to quality management system would strengthen engagement of employees into the system.

During the research, statistically significant positive correlative relationships between subjective well-being and engagement of employees in work were revealed. It can be assumed that while subjective well-being increases, employees are more engaged into work in the organization.

The research results revealed that engagement of employees into work, their behaviour with regard to the quality management system and subjective well-being are statistically significantly related. Summarizing, it can be stated that the more behaviour of employees is expressed with regard to management, the more their engagement into work will be strengthened. Thus,

\section{References}

Afarjanc, E., Serapinas, D., \& Daugvilienè, D. (2008). Employees' impact to quality management system effectiveness of higher education organization. Economics \& Management.

Ahire, S. L., \& Golhar, D. Y. (1996). Quality management in large vs small firms. Journal of small business management, 34(2), 1.

Ajzen, I. (1991). The theory of planned behavior. Organizational behavior and human decision processes, 50(2), 179-211. https://doi.org/10.1016/0749-5978(91)90020-T

Anitha, J. (2014). Determinants of employee engagement and their impact on employee performance. International journal of productivity and performance management, 63(3), 308. https:// doi.org/10.1108/IJPPM-01-2013-0008

Aryee, S., Walumbwa, F. O., Gachunga, H., \& Hartnell, C. A. (2016). Workplace Family Resources and Service Performance: The Mediating Role of Work Engagement. Africa Journal of Management, 2(2), 138-165.https://doi.org/10.1080/2332237 3.2016 .1175265

Attridge, M. (2009). Measuring and managing employee work engagement: A review of the research and business literature. Journal of Workplace Behavioral Health, 24(4), 383-398. https://doi.org/10.1080/15555240903188398

Baumruk, R. (2006). Why managers are crucial to increasing engagement: Identifying steps managers can take to engage their workforce. Strategic HR Review, 5(2), 24-27. https://doi. org/10.1108/14754390680000863

Black, S. A., \& Porter, L. J. (1996). Identification of the critical factors of TQM. Decision sciences, 27(1), 1-21. https://doi. org/10.1111/j.1540-5915.1996.tb00841.x employees will be engaged in the quality management system. During scientific literature analysis, Matthews et al. (2014) stated that engagement of employees is directly related to subjective well-being. The research results confirmed that statistically significant average positive relations were found between engagement of employees and subjective well-being. However, the impact of the latter on behaviour of employees in regard to quality management system is weak. The research data indicate that socio-demographic factors have an impact on the constructs.

\section{Acknowledgements}

This research was co-funded by a grant (No. S-MIP-17-122) from the Research Council of Lithuania.

DeVellis, R. F. (2016). Scale development: Theory and applications (Vol. 26). Sage publications.

Diener, E. D., Emmons, R. A., Larsen, R. J., \& Griffin, S. (1985). The satisfaction with life scale. Journal of personality assessment, 49(1), 71-75. https://doi.org/10.1207/s15327752jpa4901_13

Flynn, B. B., Schroeder, R. G., \& Sakakibara, S. (1994). A framework for quality management research and an associated measurement instrument. Journal of Operations management, 11(4), 339-366. https://doi.org/10.1016/S0272-6963(97)90004-8

Gaurylienè, A., \& Korsakienè, R. (2017). Work Engagament of Older Employees. Mokslas: Lietuvos Ateitis, 9(2), 143.

Gorgievski, M. J., \& Hobfoll, S. E. (2008). Work can burn us out or fire us up: Conservation of resources in burnout and engagement. Handbook of stress and burnout in health care, 2008, 7-22. Gruman, J. A., \& Saks, A. M. (2011). Performance management and employee engagement. Human Resource Management Review, 21(2), 123-136. https://doi.org/10.1016/j. hrmr.2010.09.004

Hanaysha, J. (2016). Testing the effects of employee engagement, work environment, and organizational learning on organizational commitment. Procedia-Social and Behavioral Sciences, 229, 289-297. https://doi.org/10.1016/j.sbspro.2016.07.139 Hoyle, D. (2017). ISO 9000 Quality Systems Handbook-updated for the ISO 9001: 2015 standard: Increasing the Quality of an Organization's Outputs. Routledge.

Jacobs, G. M. (2016). Application of TPB to quality management systems as basis for corporate sustainability reporting (Doctoral dissertation, University of Pretoria). 
Kahn, W. A. (1990). Psychological conditions of personal engagement and disengagement at work. Academy of management journal, 33(4), 692-724.

Kaynak, H. (2003). The relationship between total quality management practices and their effects on firm performance. Journal of operations management, 21(4), 405-435. https://doi. org/10.1016/S0272-6963(03)00004-4

Kaynak, H. (2003). The relationship between total quality management practices and their effects on firm performance. Journal of operations management, 21(4), 405-435. https://doi. org/10.1016/S0272-6963(03)00004-4

Kaziliūnas, A., \& Vyšniausikienè, L. (2014). Impact of different quality management system implementation patterns on performance outcomes. Intellectual Economics, 8(1), 140-155. https://doi.org/10.13165/IE-14-8-1-10

Kompaso, S. M., \& Sridevi, M. S. (2010). Employee engagement: The key to improving performance. International journal of business and management, 5(12), 89. https://doi.org/10.5539/ ijbm.v5n12p89

Lin, C., Chow, W. S., Madu, C. N., Kuei, C. H., \& Yu, P. P. (2005). A structural equation model of supply chain quality management and organizational performance. International journal of production economics, 96(3), 355-365. https://doi.org/10.1016/j. ijpe.2004.05.009

Lodahl, T. M., \& Kejnar, M. (1965). The definition and measurement of job involvement. Journal of applied psychology, 49(1), 24. https://doi.org/10.1037/h0021692

Macey, W. H., \& Schneider, B. (2008). The meaning of employee engagement. Industrial and organizational Psychology, 1(1), 3-30. https://doi.org/10.1111/j.1754-9434.2007.0002.x

Matthews, R. A., Mills, M. J., Trout, R. C., \& English, L. (2014). Family-supportive supervisor behaviors, work engagement, and subjective well-being: A contextually dependent mediated process. Journal of occupational health psychology, 19(2), 168. https://doi.org/10.1037/a0036012

May, D. R., Gilson, R. L., \& Harter, L. M. (2004). The psychological conditions of meaningfulness, safety and availability and the engagement of the human spirit at work. Journal of occupational and organizational psychology, 77(1), 11-37. https://doi. org/10.1348/096317904322915892

Mickaitis, A., Zaščižinskienè, G., \& Pasvenskas, T. (2009). Introducing quality management in the organizations: ehuman aspect. Economics \& Management.Pulakos, E. D., Mueller-Hanson, R. A., \& O'Leary, R. S. (2008). Performance management in the United States. Performance management systems: A global perspective, 97-114.

Mohapatra, M., \& Sharma, B. R. (2010). Study of employee engagement and its predictors in an Indian public sector undertaking. Global business review, 11(2), 281-301. https://doi. org/10.1177/097215091001100210
Mohsan, F., Nawaz, M. M., Khan, M. S., Shaukat, Z., \& Aslam, N. (2011). Are employee motivation, commitment and job involvement inter-related: Evidence from banking sector of Pakistan. International Journal of Business and Social Science, 2(17).

Noru, M. J. (2012). IBM® ' SPSS $\odot$ ' Statistics 19 Guide to Data Analysis. Prentice Hall.

Payne, A., \& Frow, P. (2005). A strategic framework for customer relationship management. Journal of marketing, 69(4), 167-176. https://doi.org/10.1509/jmkg.2005.69.4.167

Pitt-Catsouphes, M., Matz-Costa, C., \& Besen, E. (2009). Workplace flexibility: findings from the age $\&$ generations study. Issue brief, 19, 2-3.

Powell, T. C. (1995). Total quality management as competitive advantage: a review and empirical study. Strategic management journal, 16(1), 15-37. https://doi.org/10.1002/smj.4250160105

Rabindarang, S., Bing, K. W., \& Yin, K. Y. (2014). The impact of demographic factors on organizational commitment in.

Reissová, A., Šimsová, J., \& Hášová, K. (2017). Gender Differences in Employee Engagement. Littera Scripta, 2, 84-94.

Rich, B. L., Lepine, J. A., \& Crawford, E. R. (2010). Job engagement: Antecedents and effects on job performance. Academy of management journal, 53(3), 617-635. https://doi.org/10.5465/amj.2010.51468988

Robinson, D., Perryman, S., \& Hayday, S. (2004). The drivers of employee engagement. Report-Institute for Employment Studies.

Sadikoglu, E., \& Zehir, C. (2010). Investigating the effects of innovation and employee performance on the relationship between total quality management practices and firm performance: An empirical study of Turkish firms. International journal of production economics, 127(1), 13-26. https://doi.org/10.1016/j.ijpe.2010.02.013

Schaufeli, W. B., \& Bakker, A. B. (2010). Defining and measuring work engagement: Bringing clarity to the concept. Work engagement: A handbook of essential theory and research, 10-24.

Shuck, B., Reio Jr, T. G., \& Rocco, T. S. (2011). Employee engagement: An examination of antecedent and outcome variables. Human resource development international, 14(4), 427-445. https://doi.org/10.1080/13678868.2011.601587

Sutton, S., Rutter, D., \& Quine, L. (2002). Using social cognition models to develop health behaviour interventions.

Terziovski, M., \& Samson, D. (1999). The link between total quality management practice and organisational performance. International Journal of Quality \& Reliability Management, 16(3), 226-237. https://doi.org/10.1108/02656719910223728

Wey Smola, K., \& Sutton, C. D. (2002). Generational differences: Revisiting generational work values for the new millennium. Journal of organizational behavior, 23(4), 363-382. https://doi.org/10.1002/job.147 